\title{
In memoriam: William Charles "Bill" Dement, MD, Ph.D., Father of Sleep Medicine (1928-2020)
}

\author{
Emmanuel Mignot ${ }^{1}$
}

(c) Springer Nature Singapore Pte Ltd. 2020

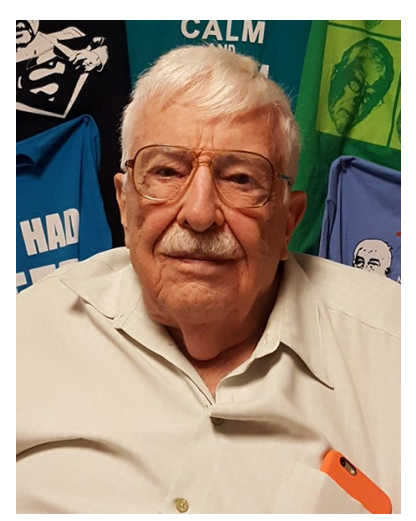

William C Dement witnessed what we called the birth of modern sleep research. Born in Wenatchee, Washington, July 1928, Dement grew up in Walla Walla. Bill became attracted to sleep research as a medical student in Chicago in 1952 working with Eugene Aserinsky and Nathaniel Kleitman shortly after their discovery of REM sleep, a moment he called the birth of modern sleep research [1]. Noticing a high brain EEG activity, the idea that REM sleep was the stage of sleep where dreams occurred [1] was proposed. He was among the first to demonstrate this association, also describing the temporal organization of REM sleep into sleep cycles $[2,3]$. His interest at the time was to explore whether this could be a door to understanding schizophrenia. Working in cats, he also confirmed these observations (after four rejections) [4] and had the opportunity to meet another giant in the field, Michel Jouvet, who we also lost recently at 91 two years ago and was the first to describe muscle atonia in REM sleep and its genesis in the pons using pontine cats

Emmanuel Mignot mignot@stanford.edu

1 Department of Psychiatry and Behavioral Sciences, Center for Narcolepsy and Sleep Disorders Center, Stanford Center for Sleep Sciences and Medicine, Stanford University School of Medicine, Palo Alto, CA 94304, USA
[5, 6]. Although neither Bill nor Michel liked very much to travel internationally, they stayed friends for life.

Although the concept that psychosis in schizophrenia as abnormal REM sleep did not end up being fruitful, Bill also quickly realized that the sleep disorder narcolepsy, first described in the 1877 [7], had all the hallmark of a disorder caused by REM sleep disturbances, paralysis, sleepiness and vivid dreaming bordering on hallucinations. Although Vogel was the first to describe sleep-onset REM periods in (SOREMPs) narcolepsy in a patient in 1960 [8], Bill had been on the trail for quite a while and published his results with Rechtschaffen [9]. In the process, he also conducted the first studies of REM sleep deprivation [10], later followed by long-term sleep deprivation (11 days).

Most importantly, Bill was one of the first to recognize the true potential of sleep research and medicine [11]. In 1970, Bill founded one of the world's first sleep disorders clinic at Stanford, first focusing on narcolepsy [12]. Using newspaper advertising, he also conducted one of the first prevalence studies of narcolepsy, finding a prevalence of $0.05 \%$ [13] remarkably similar to what was confirmed later by multiple investigators. Although the clinic closed after a year [11], it restarted with the arrival of Christian Guilleminault, who went on to coin and study obstructive sleep apnea, passing away only last year.

Bill's interest in sleep deprivation and sleepiness led him to create the first subjective sleepiness scale [14], and, with Mary Carskadon to establish the Multiple Sleep Latency Test (MSLT) [15]. In 1974, Bill wrote his first popular book on sleep named 'Some Must Watch While Some Must Sleep'. Bill's interest in narcolepsy never waned. In 1973, following a presentation at the American Medical Association, the presence of narcolepsy in a dog was suggested, leading Bill to establish a colony of donated narcoleptic canines which, like most human cases, are not genetically transmitted [16, 17]. Together with Merrill Mitler, he also adapted the MSLT to look for the presence of SOREMP and showed his utility in diagnosing narcolepsy in comparison 
to 14 controls [18]. In 1977, after discovering a litter of Dobermans affected with the condition, a stable colony was created and used to establish a research program on narcolepsy which I inherited in 1989 [19].

At the administrative front, he created the basic infrastructures that made the field so visible and vibrant. He was a co-founder of the Sleep Research Society (SRS) in 1961 and the American Sleep Disorder Association (now AASM) first president [12]. He signed the first certificate recognizing sleep medicine as a subspecialty. Bill was one of the founding editors of the journal Sleep that was established in 1978 [12]. In 1991, he shared the Sleep Research Society's Distinguished Scientist Award along with David Foulkes. Bill also jump-started and chaired the National Commission on Sleep Disorders Research that led to the establishment of the National Center in 1993 at NIH and for which he received a National Merit award. Subsequently, in 1994, the William C. Dement Academic Achievement Award was established. The purpose was to recognize members of the sleep community who have displayed exceptional initiative and progress in the areas of sleep education and academic research. In the year 2000, Bill published his popular book entitled, 'The Promise of Sleep,' which explored the link between a good night's sleep to health and happiness. For his contribution to the field of sleep, the National Sleep Foundation (NSF) awarded him with the Lifetime Achievement Award.

I first met Dr. Dement when I came to the United States in 1986. At this time, I was barely understanding English and he was without a doubt the most difficult American to understand. It is then I discovered one of Bill's greatest qualities, trusting and even more boldly empowering whoever would come his way. In my case, he gave me the responsibility of leading the center for narcolepsy at a time when funding was in difficulties, succeeding Tom Kilduff who, incidentally co-published the discovery of hypocretin with Luis De Lecea. For Bill, everything in the field was exciting, and whoever was ready to roll up their sleeves and get to work was fair game. The person would be supported. His greatest achievements are not only what he has done himself - an extraordinary feat-but also what he has encouraged and facilitated other people to do, the real hallmark of a great leader. A countless number of people have gone through Stanford and have developed their interest. His students have colonized the US and the world, starting their sleep programs with Bill being the model and inspiration for them all. He also left space for others to develop at Stanford, Christian Guilleminault first, whose loss we all still mourn, and of course Clete Kushida, many others, and myself. Bill never slowed down research or progress for anyone else in the interest of self-promotion. Rather, I have always seen him tirelessly working to help others achieve their full potential, focusing on the positive, and creating new opportunities.

I also have been humbled over the year when I have realized time after time that Bill has always had his priorities right, especially as it regards policies and vision for the sleep field. Time after time, he taught me to ask important and challenging questions that have larger implications: From clinical perspectives, what is important for people? If it works, will it make a difference in their quality of life? This was the case with narcolepsy and establishing the canine narcolepsy colony. Similarly, as a psychiatrist, he was never been afraid to promote sleep apnea as the boat that will lift all sleep medicine. We all see this as obvious now, and yet it was not as clear in the late 1980s when he was presenting data suggesting that sleep apnea was affecting up to $20 \%$ of the population and most of the audience considered him suspiciously at best. Many others did not share this open view about opening sleep research to sleep apnea and were afraid to lose control. He also predicted that insufficient sleep would be another very important area we should focus research on, and the detrimental effects of it on society are gradually unfolding in front of our eyes.

Most of all, the measure of the men may be in how many lives he has helped saved. Without Bill, sleep medicine would no doubt have eventually developed, but I feel confident that it would have taken 5 more years. Five years of misery and many thousands of lives lost to accidents and cardiovascular disease. Very few people can claim such an achievement. He was not just the father of sleep medicine, but also someone whose actions have had a real impact on all our friends and family. Goodbye Bill, your spirit leaves on.

\section{References}

1. Aserinski E, Kleitman N. Regularly occuring periods of eye motility, and concomitant phenomena, during sleep. Science. 1953;118:273-4.

2. Dement W. Dream recall and eye movements during sleep in schizophrenics and normals. J Nerv Ment Dis. 1955;122(3):263-9.

3. Dement W, Kleitman N. Cyclic variations in EEG during sleep and their relation to eye movements, body motility, and dreaming. Electroencephalogr Clin Neurophysiol. 1957;9(4):673-90.

4. Dement W. The occurrence of low voltage, fast, electroencephalogram patterns during behavioral sleep in the cat. Electroencephalogr Clin Neurophysiol. 1958;10(2):291-6.

5. Jouvet M, Michel F. Study of the cerebral electrical activity during sleep. C R Seances Soc Biol Fil. 1958;152(7):1167-70.

6. Jouvet M, Michel F. Electromyographic correlations of sleep in the chronic decorticate and mesencephalic cat. C R Seances Soc Biol Fil. 1959;153(3):422-5. 
7. Westphal C. Eigenthümliche mit Einschläfen verbundene Anfälle. Arch Psychiat. 1877;7:631-5.

8. Vogel G. Studies in psychophysiology of dreams III The dream of narcolepsy. Arch Gen Psychiatry. 1960;3:421-8.

9. Rechtschaffen A, Dement WC. Studies on the relation of narcolepsy, cataplexy and sleep with low voltage random EEG activity. In: Kety S, Evarts E, Williams H, editors. Sleep and Altered States of Consciousness. Baltimore: Williams and Wilkins; 1967. p. $488-505$.

10. Dement W. The effect of dream deprivation. Science. 1960;131(3415):1705-7.

11. Dement WC. A personal history of sleep disorders medicine. J Clin Neurophysiol Am Electroencephalogr Soc. 1990;7(1):17-47.

12. Shepard JW Jr, Buysse DJ, Chesson AL Jr, et al. History of the development of sleep medicine in the United States. J Clin Sleep Med JCSM. 2005;1(1):61-82.

13. Dement WC, Carskadon M, Ley R. The prevalence of narcolepsy II. Sleep Res. 1973;2:147.

14. Hoddes E, Zarcone V, Smythe H, Phillips R, Dement WC. Quantification of sleepiness: a new approach. Psychophysiology. 1973;10(4):431-6.
15. Carskadon MA, Dement WC, Mitler MM, Roth T, Westbrook PR, Keenan S. Guidelines for the multiple sleep latency test (MSLT): a standard measure of sleepiness. Sleep. 1986;9(4):519-24.

16. Mitler MM, Boysen BG, Campbell L, Dement WC. Narcolepsycataplexy in a female dog. Exp Neurol. 1974;45(2):332-40.

17. Foutz A, Mitler M, Cavalli-Sforza L, Dement WC. Genetic factors in canine narcolepsy. Sleep. 1979;1(4):413-21.

18. Mitler MM, Van den Hoed J, Carskadon MA, et al. REM sleep episodes during the multple sleep latency test in narcoleptic patients. Electroencephalogr Clin Neurophysiol. 1979;46(4):479-81.

19. Baker TL, Foutz AS, McNerney V, Mitler MM, Dement WC. Canine model of narcolepsy: genetic and developmental determinants. Exp Neurol. 1982;75(3):729-42.

Publisher's Note Springer Nature remains neutral with regard to jurisdictional claims in published maps and institutional affiliations. 